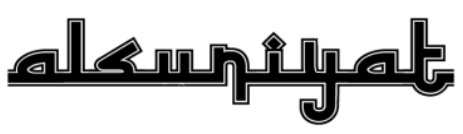

JURNAL PENELITIAN BAHASA, SASTRA, DAN

BUDAYA ARAB

P-ISSN: 2615-7241 | E-ISSN: 2721-480X // Vol. 3 No. 1 | 47-60

(7) https://ejournal.upi.edu/index.php/alsuniyat/index

\title{
INTERFERENSI BAHASA INDONESIA DALAM BAHASA ARAB: KASUS PADA KESALAHAN BERBAHASA SISWA KELAS X MAN 1 SRAGEN
}

\author{
Muna Nabila Amatullah, Lady Farah Aziza \\ Universitas Islam Negeri Sunan Kalijaga Yogyakarta, Indonesia \\ E-mail: munanabilaamatullah@gmail.com
}

\begin{abstract}
:
In the process of learning new language, language learner will experience language contact and then cause language interference. This study aims to determine (1) Forms and type of Indonesian interference found in Arabic language among class X MAN 1 Sragen; (2) factors causing language interference; and (3) solution to reduce language interference. The study used a qualitative research design. The data were collected through listening and recording method. Data were analyzed using Hubung Banding technique. The results of the study revealed that (1) language interference occurs in 214 cases contained phonological, morphological, and syntactic interference; (2) the causes of interference are bilingualism, differences on language structure between L1 and L2, and lack of vocabulary; (3) solution to reduce language interference are teacher may speak Arabic pronunciation clearly, correcting learner errors immediately, doing imla' lesson and classroom activities that help learners improve their language skill.
\end{abstract}

\section{Keywords:}

Interference; Language error; Language contact

\begin{abstract}
Abstrak:
Dalam proses pembelajaran bahasa baru, siswa akan mengalami kontak bahasa yang mengakibatkan interferensi. Tujuan penelitian ini adalah untuk mengetahui (1) bentuk dan jenis interferensi bahasa Indonesia dalam bahasa Arab pada siswa kelas X MAN 1 Sragen; (2) faktor penyebab terjadinya interferensi bahasa; dan (3) upaya untuk meminimalisirnya. Pendekatan penelitian ini adalah kualitatif deskriptif. Metode yang digunakan adalah metode simak dan catat untuk mengumpulkan data dan teknik hubung banding untuk menganalisis data. Hasil penelitian ini (1) terjadi 214 kasus kesalahan berbahasa yang terdiri dari interferensi fonologi, morfologi, dan sintaksis; (2) faktor penyebab interferensi adalah kedwibahasaan siswa, perbedaan sistem B1 dan B2, terbawanya kebiasaan B1 saat memproduksi B2, tidak cukupnya kosa kata B2; (3) solusi yang ditawarkan untuk meminimalisir interferensi adalah peniruan fonem Arab yang benar, melakukan perbaikan, menyisipkan kegiatan imla', melakukan kegiatan yang dapat menambah kosa kata Arab dan mempermudah dalam memahami perubahan fi'il.
\end{abstract}

Kata Kunci:

Interferensi; Kesalahan berbahasa; Kontak bahasa

\section{PENDAHULUAN}

Mata pelajaran bahasa Arab adalah salah satu mata pelajaran bahasa asing yang cukup banyak dipelajari oleh siswa di Indonesia, terutama di sekolahan berbasis Islam. Mata pelajaran ini dapat ditemui di berbagai jenjang pendidikan sekolah. Bahkan beberapa sekolah memperkenalkan bahasa Arab kepada siswa sejak jenjang pertama di sekolah. Hal ini terjadi mengingat bahwa mayoritas penduduk Indonesia beragama Islam, sehingga mendorong para pendidik untuk mengajarkan bahasa Arab di semua jenjang pendidikan. Dengan harapan dapat membantu mempermudah siswa dalam mempelajari bahasa Arab. 
Dalam proses mempelajarai bahasa Arab atau bahasa baru lainnya, siswa akan mengalami kontak bahasa dalam diri mereka antara bahasa yang telah dikuasainya dan bahasa yang sedang dipelajari. Mackey (dalam Suwito, 1983:39) mendefinisikan kontak bahasa sebagai pengaruh suatu bahasa dengan bahasa lainnya, sehingga melahirkan perubahan bahasa pada seorang ekabahasawan. Kontak bahasa ini akhirnya menimbulkan fenomena saling mempengaruhi antar bahasa. Kemudian bahasa yang memiliki pengaruh besar tergantung kepada tingkat penguasaan bahasa seorang pembelajar bahasa atau dwibahasawan.

Ellis (dalam Chaer, 2015:256) memaparkan bahwa para pakar pembelajaran bahasa kedua pada umumnya menyakini bahwa B1 atau bahasa yang lebih awal diperoleh mempunyai pengaruh tehadap proses pembelajaran B2 siswa. Hal senada juga diungkapkan oleh Tarigan (2011:23) bahwa dalam taraf permulaan pembelajaran bahasa kedua dapat dipastikan bahwa B1 lebih dikuasai daripada B2, sehingga dalam situasi ini pengaruh B1 sangat menonjol tehadap B2. Akibat dari pengaruh tersebut, siswa akan mentransfer sistem B1 ke dalam sistem B2, sistem yang tidak sejajar selanjutnya akan melahirkan interferensi. Interferensi merupakan kasus yang terjadi karena adanya penggunaan dua bahasa atau lebih dalam masyarakat yang bilingual atau multilingual, tidak terkecuali para siswa yang sedang belajar B2 di dalam kelas.

Hal ini sebagaimana yang dipaparkan oleh Chaer dan Agustina (2010:120) bahwa interferensi merupakan penggunaan unsur bahasa lain saat menggunakan suatu bahasa, dimana hal tersebut dianggap sebagai sebuah kesalahan karena menyimpang dari kaidah atau aturan bahasa yang digunakan. Biasanya interferensi ini terjadi dalam menggunakan B2, dan yang berinterferensi ke dalam bahasa kedua itu adalah B1, sehingga mengakibatkan adanya kesalahan berbahasa. Dalam ranah kesalahan berbahasa, interferensi B1 merupakan salah satu dari beberapa sebab terjadinya kesalahan berbahasa. Akan tetapi interferensilah yang mempunyai peran besar dalam menyumbangkan kesalahan berbahasa para siswa.

Pengajaran bahasa, kontak bahasa, interferensi, dan kesalahan berbahasa saling berkaitan satu sama lain. Berikut adalah gambar yang dapat memudahkan dalam memahami konsep tersebut. 


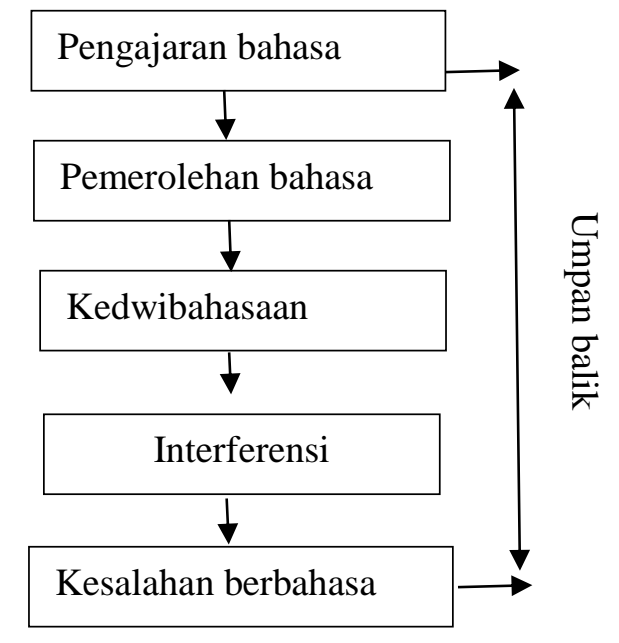

Gambar 1: Proses interferensi (Tarigan, 2011:126)

Siswa kelas X MAN 1 Sragen adalah para pembelajar bahasa Arab pemula. Kemampuan B2 yang belum baik membuat pengaruh B1 semakin kental saat memproduksi B2. Hal ini bukan sesuatu yang buruk, karena siswa sedang berada dalam proses pembelajaran terlebih para siswa adalah pembelajar bahas Arab pemula. Hal yang perlu diperhatikan adalah meningkatkan kemampuan B2 siswa, karena semakin baik kemampuan B2 maka pengaruh B1 dalam memproduksi B2 akan semakin menghilang, begitu juga sebaliknya. Seorang guru perlu melihat letak kesalahan berbahasa siswa, sehingga dapat memetakan letak kesulitan yang dihadapi siswa.

Hal tersebut selaras dengan hasil penelitian Rohmatul Faizah dan Wahyu Hanafi (2017) yang berjudul Interferensi Sintaksisi Bahasa Indonesia dalam Kemahiran Berbahasa Arab (Studi edukatif materi Insya' di Ma'had al-Jāmi'ah UIN Walisongo Semarang). Penelitian ini memaparkan tentang interferensi bahasa tataran sintaksis bahasa Indonesia dalam bahasa Arab, faktor-faktor penyebabnya dan solusi untuk meminimalisir interferensi tersebut. Hasil penelitian ini menyatakan bahwa interferensi bahasa pada tataran sintaksis dalam pembelajaran Insya' santriwati terjadi pada problem tenses dan probelm kesesuaian susunan. Interferensi bahasa tersebut terjadi karena faktor linguistik dan non-linguistik. Solusi untuk menimimalisir interferensi tersebut adalah dengan mengganti metode pengajaran yang tepat yang sesuai dengan pembelajaran, mencari teknik-teknik pengajaran yang lebih dapat membantu santriwati dalam memperbaiki kesalahannya, serta mengevaluasi materi ajar.

Hal senada juga diungkapkan oleh Choris Wahyuni (2015) dalam penelitiannya yang berjudul Interferensi Bahasa dalam Mahārah Kalām dan Kitābah: Studi Analisis pada 
Mahasiswa PBA UIN Walisongo Semester V tahun 2014. Penelitian ini membahas tentang klasifikasi interferensi bahasa Indonesia dalam bahasa Arab yang dilakukan oleh mahasiswa semester V PBA UIN Walisosngo Semarang tahun 2014 beserta faktor penyebab dan solusi yang ditawarkan untuk meminimalisirnya. Hasil penelitian ini menyatakan bahwa terjadi interferensi dalam tataran fonologi, morfologi, dan sintaksis.

Adapun faktor penyebab terjadinya interferensi adalah pemakaian bahasa Arab dalam kehidupan sehari-hari yang jarang dilakukan, kebutuhan akan sinonim, kebiasaan dalam bahasa Ibu yang terbawa saat memproduksi bahasa kedua, perbedaan antara bahasa yang dipelajari dan bahasa yang dikuasai, dan intralingual transfer. Solusi yang ditawarkan adalah mahasiswa diharapkan dapat melakukan latihan untuk meningkatkan kemampuan berbahasa Arab, dosen diharapkan memiliki kemampuan dalam bidang pedagogik maupun profesional, dosen mata kuliah insya' hendaknya merencanakan pengajaran insya' secara matang dalam memilih topik insya'.

Pemaparan di atas menunjukkan bahwa penelitian terhadap kesalahan berbahasa berupa interferensi B1 dalam B2 selama proses pembelajaran perlu dilakukan, terutama oleh para pengajar bahasa asing. Hal ini guna untuk memetakan kesulitan yang dihadapi siswa sehingga dapat menyusun strategi-strategi dan solusi dalam meninimalisir kesalahan berbahasa tersebut yang kemudian dapat meningkatkan kemampuan B2 siswa.

Berdasarkan latar belakang di atas, penulis merasa perlu untuk melakukan penelitian mengenai kesalahan berbahasa siswa kelas X MAN 1 Sragen. Penelitian ini membahas tentang jenis interferensi bahas Indonesia dalam bahasa Arab yang dilakukan oleh siswa saat memproduksi bahasa Arab. Selain itu penelitian ini juga memaparkan faktor-faktor penyebab interferensi dan solusi yang ditawarkan untuk meminimalisir interferensi tersebut. Penulis berharap penelitian ini dapat menjadi bahan pertimbangan bagi guru bahasa Arab di MAN 1 Sragen untuk meningkatkan kemampuan B2 siswa serta dapat menambah khazanah pengetahuan bagi pembaca khususnya dalam bidang interferensi dan kesalahan berbahasa.

\section{METODE}

Jenis penelitian ini adalah kualitatif. Menurut Bogdan dan Taylor (dalam Musthafa, 2018:143) penelitian kualitatif adalah prosedur penelitian yang menghasilkan data deskriptif, dimana data yang dikumpulkan berupa kata-kata tertulis atau lisan dari orang-orang dan 
perilaku yang diamati. Dalam hal ini, gejala yang diamati adalah bentuk-bentuk interferensi bahasa Indonesia dalam bahasa Arab dalam hasil terjemahan siswa kelas X MAN 1 Sragen.

Data dalam penelitian ini adalah berupa kata-kata yang mengandung interferensi dalam hasil terjemahan siswa kelas X MAN 1 Sragen. Instrument pengumpulan data penelitian ini adalah berupa tes. Tes dilakukan untuk mendapatkan hasil terjemahan sederhana siswa kelas X MAN 1 Sragen. Kemudian digunakan teknik simak dan catat untuk memperoleh data yang sesuai. Mahsun (2007:92-93) mendefinisikan teknik simak sebagai cara yang digunakan untuk memperoleh data dilakukan dengan menyimak penggunaan bahasa. Istilah menyimak disini tidak hanya berkaitan dengan penggunaan bahasa secara lisan tetapi juga penggunaan bahasa secara tertulis. Adapun teknik catat adalah teknik lanjutan ketika menerapkan teknik simak yaitu mencatat beberapa bentuk yang relevan bagi penelitian. Peneliti membaca dengan seksama kemudian mencatat atau mendokumentasikan semua kalimat yang mengandung interferensi dari sumber data yang telah ditentukan.

Data yang sudah terkumpul kemudian dianalisis menggunakan metode padan intralingual. Mahsun (2007:118-119) juga menjelaskan bahwa metode padan intralingual adalah metode analisis dengan cara menghubung-bandingkan unsur-unsur yang bersifat ligual, baik yang terdapat dalam satu bahasa maupun dalam beberapa bahasa yang berbeda. Dalam hal ini digunakan untuk mengetahui unsur-unsur lingual bahasa Indonesia yang terdapat dalam bahasa Arab. Sedangkan teknik yang digunakan dalam metode ini adalah Teknik Hubung Banding Membedakan (HBB). Teknik ini dilakukan dengan menghubungkan dan membandingkan perbedaan-perbedaan struktur bahasa Indonesia dan bahasa Arab sehingga dapat diketahui interferensi yang terjadi. Adapun langkah-langkah analisis adalah (1) mengumpulkan data; (2) mengidentifikasi kata yang mengandung interferensi; (3) mengklasifikasikan interferensi berdasarkan tataran fonologi, morfologi, dan sintaksis dan menjelaskannya; (4) merumuskan faktor-faktor yang melatarbelakangi adanya interferensi; (5) menyusun solusi untuk meminimalisir interferensi.

\section{HASIL DAN PEMBAHASAN}

\section{Interferensi Bahasa Indonesia terhadap Bahasa Arab}

Interferensi merupakan kajian yang berada dibawah payung sosiolinguistik. Interferensi adalah kesalahan bahasa berupa unsur bahasa sendiri yang dibawa ke dalam 
bahasa atau dialek lain (Kridalaksana, 2008:95). Sedangkan Kamus Besar Bahasa Indonesia (2008:560) mendefinisikan interferensi sebagai masuknya unsur-unsur suatu bahasa ke dalam bahasa lain. Istilah interferensi ini pertama kali diperkenalkan oleh Weinreich (1953) untuk menyebut adanya perubahan sistem suatu bahasa sehubungan dengan adanya persentuhan bahasa tersebut dengan unsur-unsur bahasa lain yang dilakukan oleh penutur bilingual. Kemampuan setiap para penutur bilingual bervariasi, ada penutur yang menguasai B1 dan B2 sama baiknya, dan ada penutur dan kemampuan B2 sangat minim (Chaer \& Agustina, 2010:115). Hal ini juga terjadi pada pembelajar bahasa Arab pemula, dalam hal ini yaitu siswa kelas x MAN 1 Sragen.

Berdasarkan hasil penelitian yang telah dilakukan oleh penulis, ditemukan 214 kasus kesalahan berbahasa yang terdiri dari interferensi fonologi, morfologi, dan sintaksis dalam hasil penerjemahan siswa kelas X MAN 1 Sragen.

\section{Tabel 1: Interferensi Fonologi}

\begin{tabular}{|c|c|c|c|}
\hline No & Ungkapan & Seharusnya & Keterangan \\
\hline 1 & إسِمِ & الانْمى & $\begin{array}{l}\text { Perubahan vokal panjang } \\
\text { menjadi vokal pendek }\end{array}$ \\
\hline 2 & يُسُفْ / يُوْسُوفْ/يُوُْْفْنْ & يُسُوْف & $\begin{array}{l}\text { Perubahan vokal } \\
\text { Perubahan konsonan }\end{array}$ \\
\hline 3 & اَسْتِقِاِ & أَصْدِقَائى & $\begin{array}{l}\text { Perubahan vokal } \\
\text { Perubahan konsonan }\end{array}$ \\
\hline 4 & الَّدِ & الَّلَّى & Perubahan konsonan \\
\hline 5 & زُهُرْ / دُهُز / دُوْهُوْر / زُخْر & ظُهْر & $\begin{array}{l}\text { Perubahan vokal } \\
\text { Perubahan konsonan }\end{array}$ \\
\hline 6 & أَذْهَبُ & أَذْهَبُ & Perubahan konsonan \\
\hline 7 & تَلِابُنْ & تَكَالَمِيْذُ & $\begin{array}{l}\text { Perubahan vokal } \\
\text { Perubahan konsonan }\end{array}$ \\
\hline 9 & اََهْلِيَّةُ & عَاليَّة & $\begin{array}{l}\text { Perubahan vokal } \\
\text { Perubahan konsonan }\end{array}$ \\
\hline
\end{tabular}


ALSUNIYAT: Jurnal Penelitian Bahasa, Sastra, dan Budaya Arab

\begin{tabular}{|c|c|c|c|}
\hline 10 & مَرَفِعُ & مَرَافقِقُ & $\begin{array}{l}\text { Perubahan vokal } \\
\text { Perubahan konsonan }\end{array}$ \\
\hline 11 & مَذَ & هذًا & Perubahan vokal \\
\hline 12 & هَدِهِ & هَذِهِ & Perubahan konsonan \\
\hline 13 & المَمَرَتَثَة & المَلَدَرَسَةُ & Perubahan konsonan \\
\hline 14 & عُعْوَنْ & عُعْنَانُ & Perubahan vokal \\
\hline 15 & شَرع & 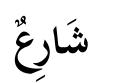 & Perubahan vokal \\
\hline 16 & فَسْلُ & فَصْنُ" & Perubahan konsonan \\
\hline 17 & كَتَبْ & كِتَّابٌ & Perubahan vokal \\
\hline 18 & إسْتَرَهَة/اِمْتَرَهَة & 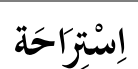 & Perubahan vokal \\
\hline & & & Perubahan konsonan \\
\hline 19 & دَهَبَ & ذَهَبَ & Perubahan konsonan \\
\hline
\end{tabular}

Berdasarkan tabel di atas, dapat dilihat bahwa siswa mengalami kesalahan dalam pelafalan kosakata B2 sehingga berakibat pada kesalahan dalam penulisan. Siswa mengucapkan fonem pada sistem B2 dengan fonem pada sistem bahasa B1 dan kemudian فَصْلْ dengan فَسْنُ. Hal ini dikarenakan dua fonem tersebut memiliki artikulasi yang mirip, dimana dalam B1 tidak mengenal kemiripan fonem demikian.

Hal ini sebagaimana yang telah dipaparkan oleh Hisyam Zaini (2013:38) bahwa alasan terjadinya perubahan fonologis terutama adalah faktor kemudahan. Pembelajar bahasa Arab yang sudah terbiasa menggunakan bahasa Indonesia, mencoba mengakomodasi sistem fonologi Arab yang disesuaikan dengan sistem fonologi bahasa Indonesia. Kemudian juga terjadi perubahan vokal, dari vokal panjang menjadi vokal pendek seperti kata شَّرع yan yang berubah menjadi شَرِع Penyimpangan ini terjadi karena dalam sistem vokal bahasa Indonesia 
tidak ada vokal panjang, seluruh vokal bahasa Indonesia adalah pendek. Siswa sudah mengetahui adanya perbedaan tersebut, tetapi karena pengaruh kebiasaan berbahasa B1 masih ada, sehingga lahirlah penyimpangan tersebut. Adanya pencampuran sistem fonologi B1 dan B2 membuktikan adanya peristiwa intererensi sintaksis pada hasil terjemahan siswa kelas x MAN 1 Sragen.

Tabel 2: Interferensi morfologi

\begin{tabular}{|c|c|c|c|}
\hline No & Ungkapan & Seharusnya & Keterangan \\
\hline 1 & أَنَا الطُلَّبَُّ & أَنَا الطَّالَبِب & $\begin{array}{l}\text { Membedakan bentuk } \\
\text { jama' dan mufrad }\end{array}$ \\
\hline 2 & أَنَا يَذْهَبُ & أَنَا أَذْهَبُ & $\begin{array}{l}\text { Perubahan fi'il } \\
\text { berdasarkan persona }\end{array}$ \\
\hline 3 & هذِِهِ أَصْدِقَأئى & هذَا صَدِيِقى & $\begin{array}{l}\text { Membedakan bentuk } \\
\text { jama' dan mufrad }\end{array}$ \\
\hline 4 & الطُّلَابُ الاسْتِركَة & الطُّلَّبُ يَسْنَرَحِوْوَنَ & Pembentukan fi'il \\
\hline 5 & طَالِبِ الاسْتِرَاحة & طَالِبٌْ يَسْتَرِيْح & Pembentukan fi'il \\
\hline 6 & نَخَنُ أُصَلِّلى & نَخْنُ نُصَلِّلى & $\begin{array}{l}\text { Perubahan fi'il } \\
\text { berdasarkan persona }\end{array}$ \\
\hline 7 & نَقَقَأُ الكُتُبَ الكُتُبَ & نَقْرَاُ الكُتُبْ & Pembentukan jama' \\
\hline 8 & تَارِيْخُ مِيْلَادِهَا & تَرَِيْخُ مِيْلَادِى & Pemilihan dhamìr \\
\hline 9 & أَنَا فُصُوْلْ & أَنَا طَالِبُ فَصْنُ الأَوَّل & $\begin{array}{l}\text { Membedakan bentuk } \\
\text { jama' dan mufrad }\end{array}$ \\
\hline 10 & أَنَا يَدْرُسُ & أَنًَا أَدْرُسُ & $\begin{array}{l}\text { Perubahan fi'il } \\
\text { berdasarkan persona }\end{array}$ \\
\hline 11 & أَنَا دَهَبَ & أَنًَا أذذهَهُ & $\begin{array}{l}\text { Perubahan fi'il } \\
\text { berdasarkan persona }\end{array}$ \\
\hline 12 & نَنَنُ يَقْرَأُ & نَخْنُ نَقْرَأُ & Perubahan fi'il \\
\hline
\end{tabular}




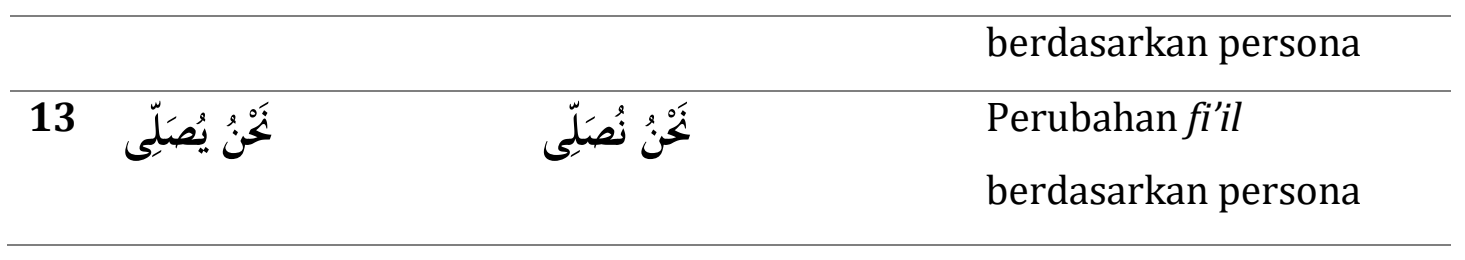

Berdasarkan tabel di atas, dapat dilihat bahwa siswa masih menggunakan kebiasaan sistem morfologi dari B1. Misalnya dalam kalimat يَذَفَْبَ siswa masih belum dapat meninggalkan kebiasaan berbahasa B1 saat memproduksi B2. Verba dalam B1 tidak membutuhkan sistem kala, persona, gender, dan jumlah sebagaimana sistem B2. Misal lainnya adalah dalam kalimat نَقَرَاً الكُتُبَ الكُتُبَ , siswa juga belum bisa meninggalkan kebiasaan berbahasa B1. Dalam B1 secara umum cara pembentukan jamak dengan menggandakan kata, seperti buku-buku dan pensil-pensil. Kemudian sistem ini masih digunakan siswa dalam membuat bentuk jamak saat memproduksi B2. Kebiasaan-kebiasaan berbahasa B1 tersebut yang terbawa saat memproduksi B2 akhirnya melahirkan interferensi bahasa. Adanya pencampuran sistem morfologi B1 dan B2 membuktikan adanya peristiwa intererensi sintaksis pada hasil terjemahan siswa kelas x MAN 1 Sragen.

Tabel 3: Interferensi sintaksis

\begin{tabular}{|c|c|c|c|}
\hline No & Ungkapan & Seharusnya & Keterangan \\
\hline 1 & هِيَ يُحَافِظُ & هُوَ يُحَافِظُ & $\begin{array}{l}\text { Membedakan mudzakkar } \\
\text { dan muannast }\end{array}$ \\
\hline 2 & المَقْصَقُ المَدْرَسة & مَقْصَقَ المَدْرَسة & $\begin{array}{l}\text { Membedakan konsep } \\
\text { idhāfy dan washfy }\end{array}$ \\
\hline 3 & أَنَا فُصُوْلٌ درسية الصَّف & أَنَا طَالِب فِف الصَّفُ الأَوَّل & $\begin{array}{l}\text { Pemilihan kosa kata dan } \\
\text { penyusunan kalimat } \\
\text { bahasa Arab }\end{array}$ \\
\hline 4 & وَسَطَ وَسَطَ فِي المَدْرَسَةَ & وَسَطَ المَدْرَسَةَ & $\begin{array}{l}\text { Penyusunan kalimat } \\
\text { bahasa Arab mengikuti } \\
\text { penyusunan kalimat } \\
\text { dalam bahasa Indonesia }\end{array}$ \\
\hline
\end{tabular}

Berdasarkan tabel di atas, dapat dilihat bahwa siswa masih belum bisa meninggalkan 
kebiasaan berbahasa B1 saat memproduksi B2. Siswa menggunakan sistem bahasa B1 ketika memproduksi B2, misalnya dalam kasus هِيَ يُحَافِظ, siswa belum bisa meninggalkan kebiasaan berbahasa B1, dimana dalam B1 tidak mengenal adanya gender. Hal ini berbeda dengan sistem B2 yang memiliki sistem gender. Adanya pencampuran sistem sintaksis B1 dan B2 membuktikan adanya peristiwa intererensi sintaksis pada hasil terjemahan siswa kelas X MAN 1 Sragen.

\section{Faktor Penyebab Terjadinya Interferensi}

Interferensi bahasa Indonesia dalam bahasa Arab yang terjadi pada hasil terjemahan siswa kelas X MAN 1 Sragen merupakan salah satu bentuk kesalahan berbahasa. Kesalahan tersebut terjadi karena dipengaruhi oleh beberapa faktor, yaitu:

\section{Kedwibahasaan siswa}

Kedwibahasaan peserta tutur dalam hal ini adalah siswa kelas X MAN 1 Sragen merupakan alasan utama terjadinya interferensi. Hal ini terjadi karena adanya kontak bahasa dalam diri para siswa tersebut, yaitu bahasa Indonesia yang telah mereka kuasai dan bahasa Arab yang sedang mereka pelajari. Bahasa Indonesia lebih dominan dibandingkan bahasa Arab, disebabkan penutur lebih menguasai bahasa Indonesia dari pada bahasa Arab. Suharto (2017:20-37) memaparkan bahwa dalam diri siswa telah ada sistem bahasa lain yang lebih dulu ada sehingga menimbulkan ketidaksempurnaan atau ketidakmampuan siswa dalam menuturkan bahasa baru. Para siswa telah menguasai bahasa Indonesia di samping bahasa Jawa sebagai B1sedangkan bahasa Arab adalah bahasa asing yang sedang mereka pelajari. Dengan demikian menunjukkan bahwa para siswa lebih menguasai bahasa Indonesia dari pada bahasa Arab.

\section{Perbedaan sistem B1 (bahasa Indonesia) dan B2 (bahasa Arab)}

Berdasarkan data yang telah dipaparkan di atas, dapat dilihat bahwa siswa mencampurkan antara sistem B1 dan sistem B2. Hal ini dikarenakan siswa belum sepenuhnya menguasai sistem B2. Perbedaan sistem antara B1 dan B2 adalah penyebab dari kesulitan siswa. B1 dalam hal ini adalah bahasa Indonesia merupakan rumpun bahasa Austronesia, sedangkan B2 dalam hal ini adalah bahasa Arab merupakan bagian dari rumpun Semit.

Soeparno (2002:33-38) memaparkan bahwa bedasarkan tipologi struktur morfologis, bahasa Indonesia merupakan tipe bahasa Aglutinatif yaitu bahasa yang struktur katanya terbentuk oleh penggabungan unsur pokok dan unsur tambahan, unsur pokok dan unsur 
pokok, atau pun pengulangan unsur pokok. Seperti proses afiksasi dengan penambahan imbuhan dalam kata 'pancing' yang merupakan kata benda, kemudian diberi imbuhan 'me-' sehingga menjadi 'memancing' dan berubah menjadi kata kerja. Sedangkan bahasa Arab merupakan tipe Fleksi yaitu bahasa yang struktur katanya terbentuk oleh perubahan kata disebabkan oleh jenis, jumlah, persona, kala. Misalnya proses perubahan kata ذَهَبَ (pergi) ketika dihadapkan pada persona dua orang femina dengan kala lampau, maka akan berubah menjadi ذَهَبَّا. Kemudian jika dihadapkan pada persona jamak maskula dengan kala kini, maka akan berubah menjadi يَذَهَبْوْنَ

Kemudian berdasarkan tipologi morfosintaksis, bahasa Indonesia termasuk tipe bahasa analitik yaitu bahasa yang setiap katanya memiliki satu konsep, dan tidak terdiri dari gabungan konsep. Seperti kata 'makan' yang hanya memiliki satu konsep yaitu kata kerja makan tanpa mengandung konsep kala, persona, jumlah, gender, dan lain sebagainya. Sedangkan bahasa Arab termasuk tipe bahasa sintetik yaitu bahasa yang satu bentuk bahasa (katakan satu bentuk kata) telah mengandung konsep makna sintaksis dan juga sekaligus merupakan hubungan sintaksis. Misalnya kata 'دَرَسَ' yang sudah mengandung beberapa konsep, yaitu kala lampau, persona tunggal dan maskula.

Oleh karena itu, beberapa perbedaan tersebut menjadi faktor penyebab sulitnya siswa dalam mempelajari bahasa Arab sebagai bahasa Asing, sehingga melahirkan interferensi bahasa.

\section{Terbawanya kebiasaan berbahasa B1 saat memproduksi B2}

Terbawanya kebiasaan B1 pada B2 yang sedang digunakan, pada umumnya disebabkan oleh kurangnya kontrol bahasa dan kurangnya penguasaan terhadap B2 (Fauziati, 2016:96-109). Dalam kasus kesalahan berbahasa siswa kelas X MAN 1 Sragen ini, terbawanya kebiasaan B1 saat memproduksi B2 disebabkan oleh kurangnya penguasaan terhadap B2. Hal ini dikarenakan para siswa tersebut merupakan pembelajar bahasa Arab pemula. Pengaruh kebiasaan berbahasa B1 tersebut akan berkurang seiring dengan bertambahnya penguasaan terhadap B2. Hal ini juga dipaparkan oleh Tarigan (2011:13-14) semakin tinggi taraf penguasaan B2 semakin kecil pengaruh B1. Pengaruh itu dapat hilang sama sekali pada saat seseorang pembicara menguasai baik B1 dan B2 dengan taraf yang sama baiknya. Dengan demikian siswa perlu meningkatkan kemampuan B2 agar pengaruh kebiasaan B1 berkurang.

\section{Solusi yang ditawarkan untuk meminimalisir interferensi}


Berdasarkan hasil penelitian yang dilakukan penulis, frekuensi interferensi terbanyak adalah interferensi fonologi. Maka dapat disimpulkan bahwa pengucapan fonem bahasa Arab siswa kelas X MAN 1 Sragen masih kurang baik, sehingga mempengaruhi dalam penulisan. Hal ini terjadi karena faktor kesulitan mengucapkan fonem-fonem yang tidak terdapat padanannya dalam B1 yaitu bahasa Indonesia dan fonem yang memiliki artikulasi yang serupa.

Dengan demikian, untuk meminimalisir adanya interferensi bahasa Indonesia dalam bahasa Arab siswa kelas X MAN 1 Sragen perlu dilakukan beberapa upaya. (1) belajar bahasa baru pada dasarnya adalah peniruan, dengan ini guru bahasa Arab diharapkan dapat memberikan contoh pelafalan fonem Arab yang baik dan benar, sehingga para siswa juga dapat menirukan dan melafalkan fonem Arab dengan baik dan benar; (2) supaya kesalahan berbahasa terutama dalam segi fonologi tidak fatal, maka ketika terjadi kesalahan dan diketahui, hendaknya guru dapat melakukan perbaikan dan menunjukkan kesalahan. Hal ini guna menjadikan siswa tidak mengulangi kembali kesalahan yang pernah dibuat; (3) menyisipkan kegiatan imla' saat pembelajaran bahasa Arab berlangsung.

Imla' merupakan salah satu kegiatan dalam pembelajaran bahasa Arab yang dilakukan untuk melatih kemampuan menulis aksara Arab dengan baik dan benar (Syamsiah, 2019: 2144). Dengan kegiatan ini siswa dapat mengetahui tulisan bahasa Arab yang baik dan benar sehingga dapat meminimalisir terjadinya kesalahan; (4) melakukan kegiatan yang dapat menambah kosa kata bahasa Arab siswa; (5) melakukan kegiatan yang dapat membuat siswa mudah dalam memahami dan menghafal bentuk perubahan fi'il, seperti menggunakan metode mnemonic dan lain sebagainya. Kegiatan seperti ini perlu dirancang oleh guru sebagaimana yang dipaparkan oleh Haniah (2018:23-24) bahwa inovasi dalam pembelajaran bahasa Arab perlu dilakukan untuk mengatasi problem kesalahan berbahasa siswa.

\section{SIMPULAN}

Berdasarkan paparan di atas tentang "Interferensi bahasa Indonesia dalam bahasa Arab, kasus pada kesalahan berbahasa siswa kelas X MAN 1 Sragen" penulis dapat mengambil kesimpulan sebagai berikut (1) kesalahan berbahasa Arab pada siswa kelas X MAN 1 Sragen yang berupa interferensi bahasa Indonesia dalam bahasa Arab.

Adapun interferensi tersebut terjadi pada tataran fonologi, morfologi, dan sintaksis. 
Sedangkan frekuensi interferensi terbanyak terjadi pada tataran fonologi; (2) faktor penyebab terjadinya interferensi yaitu kedwibahasaan siswa, perbedaan sistem B1 (bahasa Indonesia) dan B2 (bahasa Arab), terbawanya kebiasaan berbahasa B1 saat memproduksi B2; (3) solusi yang ditawarkan untuk meminimalisir interferensi adalah peniruan fonem Arab yang baik dan benar, melakukan perbaikan ketika siswa membuat kesalahan berbahasa, menyisipkan kegiatan imla', melakukan kegiatan yang dapat menambah kosa kata Arab, melakukan kegiatan yang dapat mempermudah dalam memahami perubahan fi'il.

\section{DAFTAR PUSTAKA}

Ahmad dan Abdullah. (2012). Linguistik Umum. Jakarta: Erlangga.

Chaer, Abdul \& Agustina, Leonie. (2010). Sosiolinguistik Perkenalan Awal. Jakarta: Rineka Cipta.

Chaer, Abdul. (2015). Psikolinguistik. Jakarta: Rineke cipta.

Departemen Pendidikan Nasional. (2008). Kamus Besar Bahasa Indonesia Pusat Bahasa Edisi Keempat. Jakarta: PT Gramedia Pustaka.

Faizah, R., \& Hanafi, W. (2017). Interferensi Sintaksis Bahasa Indonesia dalam Kemahiran Berbahasa Arab (Studi Edukatif materi Insya' di Ma'had al-Jāmi'ah UIN Walisongo Semarang). Jurnal Linguista 1(2), 71-78. http://doi.org/10.25273/linguista.v1i2.1975

Fauziati, E. (2016). Interferensi Gramatikal Bahasa Indonesia dalam Bahasa Inggris: Kasus pada Buku LKS Bahasa Inggris untuk SLTP di Surakarta. Jurnal Penelitian Humaniora 17(2), 96-109. https://doi.org/10.23917/humaniora.v17i2.2502

Haniah, H. (2018). Analisis Kesalahan Berbahasa Arab pada Skripsi Mahasiswa Jurusan Bahasa dan Sastra Arab. Arabi: Journal of Arabic Studies 3(1), 24-34. http://dx.doi.org/10.24865/ajas.v3i1.62

Kridalaksana, Harimurti. (2008). Kamus Linguistik Edisi Keempat. Jakarta: PT Gramedia.

Mahsun. (2007). Metode Penelitian Bahasa: Tahapan Strategi, Metode, dan Tekniknya. Jakarta: Rajawali Press.

Musthafa, M. A. (2018). Interferensi Bahasa Indonesia terhadap bahasa Arab (Analisis Interferensi dalam Pembelajaran Mahārah Kalām) Jurnal An-Nabighoh 20(2), 139-161. https://doi.org/10.32332/an-nabighoh.v20i02.1275

Soeparno. (2002). Dasar-Dasar Linguistik Umum. Yogyakarta: Tiara Wacara. 
ALSUNIYAT: Jurnal Penelitian Bahasa, Sastra, dan Budaya Arab

Suharto, T., Fauzi, A. (2017). Analisis Kesalahan Sintaksis dalam Buku Teks Bahasa Arab untuk Perguruan Tinggi Keagamaan Islam. Arabiyat: Jurnal Pendidikan Bahasa Arab dan Kebahasaaraban 4(1), 20-37. https://doi.org/10.15408/a.v4i1.5274

Syamsiyah, B. (2019). Analisis Kesalahan Berbahasa dalam Imla' Mahasiswa IAIN Salatiga. Lisania: Journal of Arabic Education and Literature 3(1), 21-44. https://doi.org/10.18326/lisania.v3i1.21-44

Tarigan, Henry Guntur. (2011). Pengajaran Analisis Kesalahan Berbahasa edisi revisi. Bandung: Angkasa.

Wahyuni. Choris. (2015). Interferensi Bahasa dalam Mahārah Kalām dan Kitābah: Studi Analisis pada Mahasiswa PBA UIN Walisongo Semester V tahun 2014. Tesis. Yogyakarta: UIN Sunan Kalijaga. 